Vol. 13 (2004): 5-17.

\title{
Composition, digestibility and nutritive value of cereals for dogs
}

\author{
Riitta Kempe, Markku Saastamoinen, Seppo Hyyppä \\ Finland,e-mail: riitta.kempe@mtt.fi \\ Kurt Smeds \\ Raisio Feed Ltd, PO Box 101, FIN-21201 Raisio, Finland
}

MTT Agrifood Research Finland, Animal Production Research, Equines, Varsanojantie 63, FIN-32100 Ypäjä,

\begin{abstract}
Most dry dog foods are based on cereals, but very little published information and few comparative studies are available on the nutritive value of various cereals in dogs. To determine the apparent nutrient digestibilities and feed values of five different autoclave-processed and ground cereals: oat groats, barley, wheat, corn and rice, a digestibility trial was carried out on twelve adult huskies according to a $6 \times 4$ cyclic changeover design. Total tract organic matter $(\mathrm{OM})$, crude carbohydrate and gross energy (GE) digestibilities were higher in rice than in all the other cereals. Apparent crude protein (CP) and acid hydrolyzed fat digestibilities of rice (80\% and $94 \%$, respectively) were as good as for oat groats ( $81 \%$ and $93 \%$ ). However, oat groats had higher OM, CP and GE digestibilities than barley, wheat and corn. The amount of digestible crude protein $\left(118 \mathrm{~g} \mathrm{~kg}^{-1} \mathrm{DM}\right)$ was higher in oat groats than in the other cereals. Digestible energy contents $\left(\mathrm{MJ} \mathrm{kg}^{-1} \mathrm{DM}\right)$ of oat groats, rice, corn, wheat and barley were 17.1, 16.0, 15.7, 15.6 and 15.5, respectively. The quantity of excreted wet faeces increased and the percentage of dry matter (DM) in faeces decreased when oat groats, barley, wheat or corn were supplemented to the basal diet, in contrast to rice, which had the opposite effect on wet faeces excretion. Oat groats are good substitutes for rice or other cereals in dry dog foods.
\end{abstract}

Key words: oat groats, wheat, barley, rice, corn, digestibility, dogs, feeding, nutritive value

\section{Introduction}

Several different cereals, such as rice, corn, wheat, barley and oats, are used in the nutrition of dogs as they are a good and inexpensive source of energy and necessary in proper industrial processing of dog foods. In most dry foods the proportion of carbohydrates is usually $30-60 \%$. As carbohydrates are often the main source of energy in dog foods, the basic information of the nutritive value of various cereals is becoming more important for the precise design and optimising of commercial and experimental dog diets. 
Kempe, R. et al. Composition, digestibility and nutritive value of cereals for dogs

Processing improves the total tract nutrient digestibility of cereals, and the digestibility values of starch and nitrogen-free extract in cooked cereals are between $89 \%$ and $99 \%$ (Moore et al. 1980, Meyer et al. 1981, Schünemann et al. 1989, Gröner and Pfeffer 1997). Moreover, dehulling significantly improves the nutritional quality of rice, oats and barley, which are harvested with the hulls attached, compared to other cereals, which lose their hulls during the threshing step and are handled as naked grains. The high crude fibre and cellulose contents of hulls have negative effects on the dry matter (DM), organic matter $(\mathrm{OM})$, crude protein $(\mathrm{CP})$, energy and mineral digestibilities of cereals in dogs (Fahey et al. 1992, Lewis et al. 1994, Kienzle et al. 2001). The crude fibre content of oats (100$150 \mathrm{~g} \mathrm{~kg}^{-1} \mathrm{DM}$ ) is twice as high as in barley, wheat and corn, and so the apparent nutrient digestibilities of oats are, in most cases, lower than of other cereals (Moore et al. 1980, Walker et al. 1994). On the other hand, dietary fibres have traditionally been used in specific diets planned for the treatment of obesity or diabetes (Blaxter et al. 1990, Nelson 1992).

Today the use of oats in dog foods is marginal, although oats have a positive image and several oats-related health claims have been made in the field of human nutrition. It has also been shown that after the dehulling process, oat groats are superior to other cereals in their nutritional content (Gröner and Pfeffer 1997). Their protein content is much higher than that found in other cereals. In addition, oats are unique among cereals in having a quite good essential amino acid balance from the nutritional standpoint (Hoseney 1986). The proteins of rice and oats share similar qualities, as $10 \%$ of their proteins in the kernel are prolamins. Cooking of oats reduces the solubility of prolamins up to $90 \%$ (SontagStrohm et al. 2001). Wheat and barley contain five times more prolamins than rice or oats. Wheat prolamins have been reported to induce gluten enteropathy in dogs (Batt et al. 1987) and, therefore, the use of wheat and barley in the nutrition of dogs has partly been replaced by rice and corn. Gluten enteropathy in dogs is similar in many respects to celiac disease in humans (Batt et al. 1984). Rice, corn and potato are all gluten-free raw materials and, thus, suitable for hypoallergenic diets of dogs (Mayer and Zentek 1998). Recent studies in humans have shown that also oats are low gluten and suitable for diets of adults with celiac disease (Janatuinen et al. 1995, 1996). This may open new opportunities for oats in the diets of gluten-sensitive dogs.

The objective of the present study was to determine the nutrient digestibilities and energy value of oat groats and compare the values with those of other cereals commonly used in the nutrition of dogs. The effect of cereals on faecal characteristics and animal health was also investigated.

\section{Material and methods}

\section{Animals and experimental procedure}

A total tract digestibility trial was conducted with twelve sled dogs, ten of which were Alaskan huskies and two Siberian huskies. The dogs were obtained from a professional racing kennel (Taminax, Leppälahti, Finland). Their ages ranged from 1.5 to 8 years, and the average live weight of the six males and six females was $21.2 \pm$ $3.1 \mathrm{~kg}$. The dogs were housed at MTT's outdoor kennel and trained regularly five times a week. At the beginning of December when the experiment began, the energy requirement of the sled dogs was at quite a high level due to training, approximately 1.75 times (7.0-8.7 $\mathrm{MJ} \mathrm{ME} \mathrm{d}^{-1}$ ) their assumed maintenance energy requirement. However, there was one exception, a lazy Siberian husky which had a very low energy requirement $(1.1 \times$ maintenance energy requirement $)$. All dogs received regular vaccinations and were treated for endoparasites. They remained healthy over the duration of the study, according to routine physical examinations, blood chemistries and blood cell counts. The experimental protocol was approved by the Animal Experiment 
Vol. 13 (2004): 5-17.

Committee of the MTT Agrifood Research Finland.

The experimental design was a $6 \times 4$ cyclic changeover (Davis and Hall 1969). The dogs were allocated on the basis of their energy requirement into two experimental blocks. Within the block the dogs were randomly allocated to six experimental treatments (A-F) each dog having four different treatments during the experiment. Oat groats, barley, wheat, corn and rice were the cereal sources in the treatments. The cereals were processed according to feed factory's (Raisio Feed Ltd) normal procedure in autoclave $\left(140^{\circ} \mathrm{C}, 3 \mathrm{bar}, 30 \mathrm{~min}\right)$ and ground through a $2 \mathrm{~mm}$ sieve. The proportion of cereals in the experimental diets was $30 \%$, as a $40 \%$ cereal supplementation induced diarrhoea in sled dogs during training. The digestibility of each cereal source was calculated by difference, because their unsuitability as the sole item in the diet. Commercial extruded dog food (Baron ${ }^{\circledR}$ Exel, Rehuraisio Oy, Finland) was used as the basal diet. The ingredients of the dry dog food were corn $(20.0 \%)$, animal fats $(17.7 \%)$, meat meal $(14.3 \%)$, corn gluten $(12.0 \%)$, meat and bone meal $(11.4 \%)$, poultry meal $(10.0 \%)$, fish meal $(5.7 \%)$, vegetable oils $(2.9 \%)$, aroma mixture $(2.9 \%)$, glucose $(1.1 \%)$, vitamin and mineral mixture $(1.0 \%), \mathrm{NaCl}(0.6 \%)$ and lecithin $(0.4 \%)$. Table 1 shows the composition of the experimental diets.

The dogs were kept in metabolism cages through the quantitative faeces collection period. Over the four experimental periods of fourteen days each, there was preliminary feeding for six days followed by three days of collection. The dogs were put into the metabolic cages during the last adjustment day. Total faeces was collected daily between 0800 and 2100 and stored at $-18^{\circ} \mathrm{C}$ until analysed at the end of the experiment. The transition period between experimental periods was five days.

The food allowance was kept constant for the whole nine-day preliminary feeding and collection period. Dogs were fed twice a day (9001000 and 1500-1600). The daily food portion was $500-580 \mathrm{~g}$, which was mixed with warm water 20 minutes before feeding. As the training intensity of the sled dogs diminished at the start of the racing season, their energy need decreased as well. At the beginning of each period, the feeding level was adjusted to maintain the dogs' ideal body weight, determined subjectively by the author. The body weights were recorded at the beginning and end of each feeding period. The dogs had ad libitum access to water.

Table 1. Calculated chemical composition of the diets, $\mathrm{g} \mathrm{kg}^{-1}$ dry matter.

\begin{tabular}{|c|c|c|c|c|c|c|}
\hline & $\begin{array}{l}\text { Dry food } \\
\text { basal diet }\end{array}$ & $\begin{array}{c}\text { Oat groats } \\
\text { diet }\end{array}$ & $\begin{array}{c}\text { Barley } \\
\text { diet }\end{array}$ & $\begin{array}{c}\text { Wheat } \\
\text { diet }\end{array}$ & $\begin{array}{c}\text { Corn } \\
\text { diet }\end{array}$ & $\begin{array}{c}\text { Rice } \\
\text { diet }\end{array}$ \\
\hline Organic matter & 886.6 & 912.9 & 912.8 & 914.3 & 914.8 & 912.6 \\
\hline Ash & 113.4 & 87.1 & 87.2 & 85.7 & 85.2 & 87.4 \\
\hline Crude Protein & 369.1 & 304.4 & 299.7 & 302.0 & 290.1 & 296.0 \\
\hline Acid hydrolysed fat & 247.5 & 199.3 & 183.8 & 182.9 & 192.5 & 182.2 \\
\hline Crude fibre & 13.8 & 19.1 & 22.2 & 17.4 & 17.0 & 11.7 \\
\hline $\mathrm{N}$-free extract & 256.3 & 390.0 & 407.0 & 411.9 & 415.3 & 422.7 \\
\hline Crude carbohydrates & 270.1 & 409.1 & 429.3 & 429.3 & 432.3 & 434.4 \\
\hline Starch & 209.8 & 322.1 & 321.4 & 338.4 & 356.1 & 389.1 \\
\hline$\beta$-glucan & 6.2 & 15.6 & 15.3 & 6.3 & 4.7 & 4.6 \\
\hline Total dietary fibre & 61.0 & 81.1 & 97.4 & 82.3 & 78.5 & 53.5 \\
\hline Acid detergent fibre & 11.0 & 18.5 & 22.1 & 16.8 & 14.9 & 9.9 \\
\hline Permanganate lignin & 0.0 & 0.9 & 1.1 & 1.7 & 0.0 & 1.2 \\
\hline
\end{tabular}

1 Calculated mineral composition of the dry food was ( $\left.\mathrm{kg}^{-1} \mathrm{DM}\right)$ : Ca $29 \mathrm{~g}, \mathrm{P} 16 \mathrm{~g}, \mathrm{Mg} 4 \mathrm{~g}, \mathrm{Na} 5 \mathrm{~g}, \mathrm{NaCl} 13 \mathrm{~g}, \mathrm{Cu} 15.8 \mathrm{mg}$ and Se $0.2 \mathrm{mg}$. Vitamin content of the dry food was: vitamin A $10000 \mathrm{IU}$, vitamin $\mathrm{D}_{3} 1000$ and vitamin E $100 \mathrm{IU}$. 
Kempe, R. et al. Composition, digestibility and nutritive value of cereals for dogs

Faecal samples were dried at $100^{\circ} \mathrm{C}$ for one hour and then at $60^{\circ} \mathrm{C}$ for 72 hours. Samples were ground through a $1 \mathrm{~mm}$ sieve before analysis. The dry matter content of the samples was determined by drying at $105^{\circ} \mathrm{C}$ for 16 hours. Ether extract was determined after acid hydrolysis with $4 \mathrm{~N} \mathrm{HCl}$. The contents of ash, acid hydrolysed fat and crude fibre content were determined by standard methods (AOAC 1990). Nitrogen (N) was determined from fresh samples using the Kjeldahl-technique and crude protein was obtained by multiplying the $\mathrm{N}$ content by 6.25 . Nitrogen free extract (NFE) and crude carbohydrates were obtained by difference: 1000-(ashcrude protein-acid hydrolyzed fat-crude fibre) and 1000-(ash-crude protein-fat), respectively. Acid detergent fibre (ADF) and permanganate lignin were determined by the method of Robertson and Van Soest (1981). Total dietary fibre of the feeds was determined by a modified method of Lee et al. (1992). Starch concentration of the feeds was determined according to McCleary et al. (1994) and $\beta$-glucans according to McClearly and Codd (1991). Gross energy of the samples was measured with an adiabatic bomb calorimeter (IKA C 400 Kalorimeter, Janke \& Kunkel GmbH, Staufen, Germany). Faecal consistency was evaluated subjectively according to Sunvold et al. (1995).

Blood samples were collected at the end of each feeding period for glucose and insulin analysis. The first blood samples $\left(\mathrm{T}_{0}\right)$ were taken after a 17 hours' fast and before morning feeding. Postprandial blood samples were taken $0.5\left(\mathrm{~T}_{1}\right)$, $1\left(\mathrm{~T}_{2}\right), 1.5\left(\mathrm{~T}_{3}\right), 2\left(\mathrm{~T}_{4}\right), 4\left(\mathrm{~T}_{5}\right)$ and $6\left(\mathrm{~T}_{6}\right)$ hours after feeding. Blood samples for glucose measurements were taken from the cephalic vein into vacuum tubes containing EDTA and sodium fluoride, and for insulin measurements into serum tubes with a coagulation activator. Serum was separated by centrifugation and stored at $-20^{\circ} \mathrm{C}$ until analysis. Serum concentration of glucose was analysed with an automatic analyser (KONE Pro Selective Chemistry Analyser, Espoo, Finland) using commercially available kits (Konelab Glucose, Thermo Clinical Labsystems Oy, Espoo, Finland). Serum insulin concentration was analysed by a standard method (Insulin ${ }^{125} \mathrm{I}$ RIA Kit, Incstar Corporation, Stillwater, USA) with an automatic analyser (1270 Rackgamma II, Wallac, Turku).

\section{Equations and statistical analysis}

The apparent total tract digestibility coefficients of the nutrients in the experimental diets were calculated by an equation (Schneider and Flatt 1975): digestibility coefficient of the nutrient = (nutrient intake, g - nutrient in faeces, g) / nutrient intake, g x 100. As cereals can't be fed alone for sled dogs in training, the digestibility coefficients of the cereals were estimated indirectly by feeding them with balanced dry food of known digestibility and deducting the estimated effect of the cereals in the calculations (Schneider and Flatt 1975): digestibility coefficient of the nutrient $=$ [nutrient intake from the cereal, $g-($ the total amount of nutrient in faeces, $g$ - the amount of nutrient in faeces coming from the basal diet, $\mathrm{g})$ ] / nutrient intake from the cereal, $g$.

Statistical analyses were carried out using the MIXED procedure of SAS (SAS 1998). The digestibility data were analysed by the following model: $\mathrm{Y}_{\mathrm{ijkl}}=\mu+\mathrm{B}_{\mathrm{i}}+\mathrm{A}\left(\mathrm{B}_{\mathrm{i}}\right)_{\mathrm{j}}+\mathrm{P}_{\mathrm{k}}+\mathrm{D}_{\mathrm{l}}+\mathrm{e}_{\mathrm{ijk} \mathrm{l}}$, where $\mu$ is the overall mean, $B_{i}$ is the fixed effect of the $i^{\text {th }}$ block $(i=1,2), A\left(B_{i}\right)_{j}$ are the random effect of the $j^{\text {th }}$ animal within block $(j=1, \ldots$, 6), $\mathrm{P}_{\mathrm{k}}$ are the fixed effect of the $\mathrm{k}^{\text {th }}$ period $(\mathrm{k}=$ $1, \ldots, 4)$ and $D_{1}$ are the fixed effect of the $1^{\text {th }}$ dietary treatment $(1=1, \ldots, 5)$, respectively, and $\mathrm{e}_{\mathrm{ijk}}$ are the normally distributed residuals with a mean of 0 and variance of $\sigma^{2}$.

The data obtained from blood glucose and serum insulin concentrations were analysed with the MIXED procedure of SAS for repeated measures using the model: $Y_{i j k l m}=\mu+B_{i}+A\left(B_{i}\right)_{j}+P_{k}$ $+\mathrm{D}_{1}+\mathrm{T}_{\mathrm{m}}+(\mathrm{T} \times \mathrm{P})_{\mathrm{km}}+(\mathrm{T} \times \mathrm{D})_{\mathrm{lm}}+(\mathrm{T} \times \mathrm{B})_{\mathrm{im}}+$ $(\mathrm{T} \times \mathrm{A})_{(\mathrm{i}) \mathrm{jm}}+(\mathrm{P} \times \mathrm{A})_{(\mathrm{i}) \mathrm{jk}}+\mathrm{e}_{\mathrm{ijklm}}$, where $\mathrm{T}_{\mathrm{m}}$ is time effect and $\mathrm{T} \times \mathrm{P}, \mathrm{T} \times \mathrm{D}$ and $\mathrm{T} \times \mathrm{B}$ are time by period, time by dietary treatment and time by block interactions, respectively. Animal within block, time by animal within block, period by animal within block interaction effects and er- 
Vol. 13 (2004): 5-17.

ror term are random effects. Akaike's information criterion (AIC) was used to compare the models with different covariance structures for repeated measurements. The residuals were checked for normality by plotting residuals against fitted values. Differences among treatments were tested with the Tukey test when appropriate.

\section{Results and discussion}

\section{Chemical composition of the cereals}

The chemical composition of the cereals is reported in Table 2. The dry matter and organic matter concentrations were similar among the cereals. Oat groats had a higher protein content (145 $\mathrm{g} \mathrm{kg}^{-1} \mathrm{DM}$ ) compared to barley, wheat, corn and rice. The protein contents of rice and corn were lower than of the other cereals. The starch and nitrogen free extract contents of oat groats were similar to barley but lower than of rice, corn or wheat. Oats' starch content was in the range of the values (50-60\%) reported by Abrahamsson (1992) and Oksman-Caldentay et al. (1999).
A high proportion of the amylose in oats, about $26 \%$ compared to $13-20 \%$ for wheat and barley, is lipid-complexed due to the relatively high lipid content in oat starch (Åman and Fredriksson 2001). The lipid content of oats varies quite widely, and values as low as $3 \%$ and as high as $12 \%$ have been reported (Hoseney 1986). Most Finnish oats varieties have a fat content of 510\% DM (Kempe et al. 2001). Oats also contain a lot of unsaturated acids and essential fatty acids like linoleic acid (McMullen 1991).

Cellulose is the major component in the hulls, and so those cereals that are used with their hulls intact contain more cellulose. Hulls represent about $25 \%$ of the total weight of oats (Hoseney 1986). The dehulling process lowered the crude fibre and ADF contents of oats considerably, but their contents were still higher than in the other cereals. The contents of cell wall as well as soluble fibre constituents were low in rice. The subaleurone layer in oat bran and cell walls in barley were rich in $\beta$-glucan $(\sim 4 \% \mathrm{DM})$, whereas wheat, corn and rice contained less than $1 \% \mathrm{DM}$ of $\beta$-glucan. It seems that $\beta$-glucan is an easily fermentable energy source for canine ileal microflora, as barley and oats resulted in high total short-chain fatty acid, butyrate and lactate concentrations in a recent study by Bednar et al.

Table 2. Analysed composition of cereals, $\mathrm{g} \mathrm{kg}^{-1}$ dry matter.

\begin{tabular}{|c|c|c|c|c|c|}
\hline & Oat groats & Barley & Wheat & Corn & Rice \\
\hline Dry matter, $\mathrm{g} \mathrm{kg}^{-1}$ & 896.8 & 903.5 & 900.9 & 885.7 & 890.7 \\
\hline Organic matter & 977.4 & 976.7 & 981.9 & 985.0 & 976.9 \\
\hline Ash & 22.6 & 23.3 & 18.1 & 15.0 & 23.2 \\
\hline Crude Protein & 145.3 & 130.2 & 137.8 & 93.2 & 115.0 \\
\hline Acid hydrolysed fat & 80.9 & 28.5 & 24.8 & 55.5 & 20.7 \\
\hline Crude fibre & 32.1 & 42.9 & 26.3 & 24.9 & 6.5 \\
\hline $\mathrm{N}$-free extract & 719.0 & 775.1 & 793.0 & 811.4 & 834.7 \\
\hline Crude carbohydrates & 751.2 & 818.0 & 819.3 & 836.3 & 841.2 \\
\hline Starch & 598.3 & 594.0 & 653.4 & 720.4 & 833.0 \\
\hline$\beta$-glucan & 38.6 & 37.4 & 6.4 & 0.9 & 0.5 \\
\hline Total dietary fibre & 130.4 & 186.3 & 134.3 & 122.1 & 34.8 \\
\hline Acid detergent fibre & 36.9 & 49.2 & 30.9 & 24.5 & 7.2 \\
\hline Permanganate lignin & 3.1 & 3.9 & 5.8 & 0.0 & 4.1 \\
\hline
\end{tabular}


Kempe, $R$. et al. Composition, digestibility and nutritive value of cereals for dogs

(2001). $\beta$-glucan has also aroused great interest in human nutrition studies lately, since it has been found to be able to reduce the blood glucose and insulin responses and serum cholesterol values after meals (Anderson et al. 1984, Klopfenstein 1988, Davidson et al. 1991).

\section{Digestibility of the diets}

The total tract nutrient digestibilities of the diets calculated by difference are shown in Table 3. Altogether four observations from the diets supplemented with oat groats, barely, corn and rice were removed due to low intake. After removal of the deviating results the nutrient digestibility data were normally distributed. The apparent nutrient digestibilities of the diets were in most cases lower in the first feeding period than in the latter periods. This may be due to a higher feeding level in the first feeding period. The energy need of the sled dogs decreased slightly during the experiment and their food intake was adjusted accordingly.

The apparent digestibilities of $\mathrm{OM}(\mathrm{P}<0.01)$, crude carbohydrates $(\mathrm{P}<0.001)$ and gross energy $(\mathrm{GE})(\mathrm{P}<0.01)$ were higher in the rice diet than in the oat groats and other diets. The oat groats diet had higher digestibility of $\mathrm{OM}(\mathrm{P}<$ $0.05)$, crude protein $(\mathrm{P}<0.01)$ and $\mathrm{GE}(\mathrm{P}<0.05)$ when compared with the wheat, barley or corn diets. The crude protein digestibilities of the oat groats and rice diets were approximately the same, $81 \%$ and $80 \%$, respectively. Crude protein content of the diets seemed to be positively correlated on protein digestibility as in the study of Kendall and Holme (1982). Acid hydrolyzed fat digestibility was high in all diets. However, the apparent fat digestibility decreased $(\mathrm{P}<0.05)$ when cereals, except for rice, were supplement-

Table 3. Apparent total tract digestibilities (\%) and nutritive value of the diets; estimated least square means, standard error of mean (SEM) and statistical significance $(\mathrm{P})$.

\begin{tabular}{|c|c|c|c|c|c|c|c|c|c|}
\hline & $\begin{array}{r}\text { Basal } \\
\text { diet }\end{array}$ & $\begin{array}{r}\text { Oat } \\
\text { groats } \\
\text { diet }\end{array}$ & $\begin{array}{r}\text { Barley } \\
\text { diet }\end{array}$ & $\begin{array}{r}\text { Wheat } \\
\text { diet }\end{array}$ & $\begin{array}{r}\text { Corn } \\
\text { diet }\end{array}$ & $\begin{array}{r}\text { Rice } \\
\text { diet }\end{array}$ & $\mathrm{SEM}_{1}$ & $\mathrm{SEM}_{2}$ & $\begin{array}{r}F \\
P \leq\end{array}$ \\
\hline Observations & 8 & 7 & 7 & 8 & 7 & 7 & & & \\
\hline Dry matter & $76.5^{\mathrm{ab}}$ & $79.3^{c}$ & $76.8^{\mathrm{a}}$ & $77.1^{\mathrm{a}}$ & $74.8^{\mathrm{b}}$ & $81.7^{\mathrm{d}}$ & 0.70 & 0.75 & 0.001 \\
\hline Organic matter & $85.1^{\mathrm{a}}$ & $85.3^{\mathrm{a}}$ & $82.8^{\mathrm{bc}}$ & $83.5^{\mathrm{b}}$ & $81.4^{\mathrm{c}}$ & $87.9^{\mathrm{d}}$ & 0.55 & 0.59 & 0.001 \\
\hline Ash & $9.9^{\mathrm{ab}}$ & $15.9^{\mathrm{ab}}$ & $14.4^{\mathrm{ab}}$ & $9.5^{\mathrm{bc}}$ & $2.7^{\mathrm{c}}$ & $17.5^{\mathrm{a}}$ & 2.85 & 3.06 & 0.02 \\
\hline Crude protein & $81.3^{\mathrm{a}}$ & $80.8^{\mathrm{a}}$ & $77.4^{\mathrm{b}}$ & $77.7^{\mathrm{b}}$ & $74.5^{\mathrm{c}}$ & $79.7^{\mathrm{ab}}$ & 0.81 & 0.87 & 0.001 \\
\hline Acid hydrolysed fat & $94.5^{\mathrm{a}}$ & $93.2^{\mathrm{bc}}$ & $93.1^{\mathrm{c}}$ & $92.2^{\mathrm{cd}}$ & $92.0^{\mathrm{d}}$ & $94.2^{\mathrm{ab}}$ & 0.38 & 0.41 & 0.001 \\
\hline Crude carbohydrates & $81.6^{\mathrm{b}}$ & $84.8^{\mathrm{a}}$ & $82.3^{\mathrm{ab}}$ & $83.8^{\mathrm{a}}$ & $81.3^{b}$ & $90.8^{\mathrm{c}}$ & 0.72 & 0.77 & 0.001 \\
\hline Gross energy & $86.5^{\mathrm{a}}$ & $85.9^{\mathrm{a}}$ & $83.6^{\mathrm{bc}}$ & $84.1^{\mathrm{b}}$ & $82.3^{\mathrm{c}}$ & $88.1^{\mathrm{d}}$ & 0.51 & 0.55 & 0.001 \\
\hline \multicolumn{10}{|l|}{ Feed values } \\
\hline $\begin{array}{l}\text { Gross energy, } \\
\mathrm{MJ} \mathrm{kg}^{-1} \mathrm{DM}\end{array}$ & 22.96 & 22.07 & 21.67 & 21.68 & 21.83 & 21.57 & & & \\
\hline $\begin{array}{l}\text { Digestible energy, } \\
\mathrm{MJ} \mathrm{kg}^{-1} \mathrm{DM}\end{array}$ & 19.87 & 18.94 & 18.15 & 18.22 & 18.00 & 18.98 & & & \\
\hline $\begin{array}{l}\text { Digestible crude } \\
\text { protein, } \mathrm{g} \mathrm{kg}^{-1} \mathrm{DM}\end{array}$ & 300 & 246 & 233 & 235 & 217 & 236 & & & \\
\hline
\end{tabular}

$\mathrm{SEM}_{1}$ is for least square-means of basal and wheat diets.

$\mathrm{SEM}_{2}$ is for least square-means of oat groats, barley, corn, and rice diets.

$\mathrm{a}, \mathrm{b}, \mathrm{c}, \mathrm{d}$ Means with the same row followed by the same letters do not differ significantly $(\mathrm{P} \geq 0.05)$. 
Vol. 13 (2004): 5-17.

ed to the basal diet. This can be explained in part by lower fat intake of around $4.1-4.5 \mathrm{~g} \mathrm{~kg}^{-1}$ body weight in the cereal supplemented diets compared to fat intake of $5.9 \mathrm{~g}$ in the basal diet as the digestibility of fat starts to decrease in the function of intake. Digestibility of fat in the oat groats diet $(93 \%)$ was higher $(\mathrm{P}<0.05)$ than in the corn diet (92\%). Apparent crude carbohydrate digestibility increased $(\mathrm{P}<0.05)$ when rice, oat groats or wheat were supplemented in the basal diet. The digestibility of crude carbohydrates was highest in the rice diet, on average $91 \%$. The oat groats and wheat diets had almost equal crude carbohydrate digestibilities: $85 \%$ and $84 \%$, respectively. The digestibility of crude carbohydrates was higher in the oat groats diet than in the barley $(\mathrm{P}<0.05)$ or corn $(\mathrm{P}<0.01)$ diets. High crude fibre and ADF content of barley diet probably induced decreased apparent digestibility of crude carbohydrates. Indigestible crude fibre and ADF contents of the diets had not clear effect on the apparent digestibility of OM, fat and protein even if the ADF content ranged from $22 \%$ in barley diet to $10 \%$ in rice diet. However, high crude fibre and ADF content may have little decreased the apparent digestibility of energy.

\section{Effect of cereal supplementation on faecal characteristics}

Wet weight, faecal dry weight, faecal DM and faecal score data are presented in Table 4. The quantity of excreted wet faeces increased when barley, wheat or corn was supplemented in the basal diet $(\mathrm{P}<0.01)$, in contrast to rice, which had an opposite effect on wet faeces excretion. Faecal wet weights for dogs fed barley, wheat or corn diets were approximately $17 \%$ higher than the average faecal wet weights of dogs consuming the basal or oat groats diets, and $31 \%$ higher when compared with the rice diet. Dogs fed the corn, barley and basal diets had approximately $24 \%(\mathrm{P}<0.001)$ and $13 \%(\mathrm{P}<0.05)$ greater faecal dry weights than dogs on the rice and oat groats diets, respectively, reflecting the lower digestibilities of DM and OM. The percentage of DM in faeces decreased from $37 \%$ in dogs fed the basal diet to approximately $30 \%$ in dogs fed oat groats, barley, wheat or corn $(\mathrm{P}<0.001)$. The percentage of DM in faeces was $34 \%$ in rice diet. Consumption of the barley and oat groats diets resulted in higher faecal scores compared with the basal diet $(\mathrm{P}<0.05)$, indicating looser stools. High water-holding capacity of the soluble fibre fraction (mainly $\beta$-glucan) found in barley and oat groats accounts for the decreased faecal DM as well as the higher faecal scores. Although the dogs produced mainly faeces of optimal scores when consuming these diets, an occasional ranking of 4 (soft, pudding-like, and unform) and 5 (watery, liquid) was recorded. This may indicate an excessive amount of cereals (total of $50 \%$ ) in the diets of sled dogs as well as a slight stress in the dogs, induced by the collection period and blood sampling.

Murray et al. (1999) reported that barleybased diets increase the quantity of excreted faeces by $32 \%$ compared with corn, potato, rice, sorghum and wheat diets. The fibre components of barley have a high water-holding capacity, which accounts for the increased faecal amount excreted. An excess amount of barley (> 50\%) in the diet of dogs decreased faecal DM and may induce loose stools or diarrhoea (Murray et al. 1999).

\section{Digestibility and feed values of the cereals}

The total tract nutrient digestibilities of the cereals, calculated by difference, are shown in Table 5 . The total tract organic matter digestibility was higher in rice than in the other cereals $(\mathrm{P}<$ 0.01). Corn had the lowest OM digestibility. Oat groats had a higher OM digestibility than wheat or barley $(\mathrm{P}<0.05)$, which did not differ significantly in $\mathrm{OM}$ digestibility. The organic matter digestibilities of the autoclaved cereals used in this study were lower than the values reported by Gröner and Pfeffer (1997) for extruded cere- 
Kempe, R. et al. Composition, digestibility and nutritive value of cereals for dogs

Table 4. Faecal characteristics of dogs consuming diets supplemented with various cereals; estimated least square means, standard error of mean (SEM) and statistical significance $(\mathrm{P})$.

\begin{tabular}{|c|c|c|c|c|c|c|c|c|c|}
\hline & $\begin{array}{r}\text { Basal } \\
\text { diet }\end{array}$ & $\begin{array}{r}\text { Oat groats } \\
\text { diet }\end{array}$ & $\begin{array}{r}\text { Barley } \\
\text { diet }\end{array}$ & $\begin{array}{r}\text { Wheat } \\
\text { diet }\end{array}$ & $\begin{array}{r}\text { Corn } \\
\text { diet }\end{array}$ & $\begin{array}{r}\text { Rice } \\
\text { diet }\end{array}$ & $\mathrm{SEM}_{1}$ & $\mathrm{SEM}_{2}$ & $\begin{array}{r}\mathrm{F} \\
\mathrm{P} \leq\end{array}$ \\
\hline Observations & 8 & 7 & 7 & 8 & 7 & 7 & & & \\
\hline Faecal wet weight, $\mathrm{g} \mathrm{d}^{-1}$ & $978^{\mathrm{b}}$ & $1026^{\mathrm{b}}$ & $1184^{\mathrm{c}}$ & $1180^{c}$ & $1274^{c}$ & $837^{\mathrm{a}}$ & 49.13 & 52.90 & 0.001 \\
\hline Faecal dry weight, $\mathrm{g} \mathrm{d}^{-1}$ & $355^{\mathrm{cd}}$ & $318^{b}$ & $355^{\mathrm{cd}}$ & $350^{c}$ & $383^{d}$ & $278^{a}$ & 10.74 & 11.56 & 0.001 \\
\hline Faecal dry matter, $\%$ & $36.6^{\mathrm{c}}$ & $31.1^{\mathrm{a}}$ & $30.2^{\mathrm{a}}$ & $29.6^{\mathrm{a}}$ & $29.8^{\mathrm{a}}$ & $34.2^{\mathrm{b}}$ & 0.85 & 0.90 & 0.001 \\
\hline Faecal consistency score ${ }^{1}$ & $2.5^{\mathrm{a}}$ & $3.0^{\mathrm{bc}}$ & $3.0^{\mathrm{bd}}$ & $2.5^{\mathrm{ac}}$ & $2.5^{\mathrm{acd}}$ & $2.5^{\mathrm{a}}$ & 0.19 & 0.20 & 0.024 \\
\hline
\end{tabular}

a, b, c, d Means with the same row followed by the same letters do not differ significantly (P $\geq 0.05)$.

1 Faecal samples were scored according to the following system (Sunvold et al. 1995): $1=$ hard, dry pellets with small hard mass; 2 = hard, formed, dry stool that remained firm and soft; $3=$ soft, formed, moist with softer stool that retained shape; 4 = soft, unformed stool that assumed shape of container, pudding-like; $5=$ a watery liquid that could be poured.

als. In their trials, the apparent OM digestibilities of oat groats, dehulled barley, wheat, corn and rice were $93 \%, 92 \%, 86 \%, 88 \%$ and $98 \%$, respectively.

Apparent crude protein digestibility was better and the amount of digestible crude protein was higher in oat groats than in wheat, barley or corn $(\mathrm{P}<0.01)$. Only the $\mathrm{CP}$ digestibility of rice was as good as for oat groats presumably because of its very low crude fibre content. However, the amount of digestible crude protein and the quality of protein were lower in rice than in oat groats. An additive adverse effect of high fibre and starch content on faecal protein digestibility found in the study of Kienzle et al. (2001) may also explain $\mathrm{CP}$ digestibility of barley in our experiment. Corn had the lowest crude protein content and digestibility. Hoseney (1986) suggested that bonds between protein and starch components of corn are quite strong and this structural difference may reduce digestibility. The crude protein digestibilities of the cereals were in the range of values reported by Moore et al. (1980) for extruded oats, rice and corn. However, the cereal CP digestibilities were higher than in the study of Gröner and Pfeffer (1997), except for wheat. In their trials, the apparent protein digestibilities of oat groats, dehulled barley, wheat, corn and rice were 75\%, 71\%,83\%, $71 \%$ and $71 \%$, respectively. Murray et al. (1999) obtained lowest ileal digestibility values of $\mathrm{CP}$ for corn $(73 \%)$ and similar for barley $(81 \%)$, wheat $(82 \%)$ and rice $(76 \%)$. Their total tract digestibility values were higher than ileal values, $87 \%, 83 \%, 85 \%$ and $85 \%$, respectively. Kendall and Holme (1982) obtained fairly high CP digestibility values for raw barley and wheat meals, $73-82 \%$ and $81 \%$, respectively, as well as for flaked corn, which had a CP digestibility of $78 \%$.

The acid hydrolyzed fat digestibilities of the cereals were high (92-94\%). Rice, oat groats and barley had similar fat digestibilities. Oat groats and rice had a higher fat digestibility than corn $(\mathrm{P}<0.05)$, which is commonly used as a highfat cereal component in dog foods but had the lowest fat digestibility in our study. This result is inconsistent with a recent study by Gröner and Pfeffer (1997), in which the fat digestibility of corn $(98 \%)$ was higher than of dehulled oats (92\%). In the study of Murray et al. (1999) ileal and total tract fat digestibilities of barley, corn, rice and wheat were high $90-94 \%$ and $92-94 \%$, respectively and comparable to our results. Kendall and Holme (1982) obtained fairly low fat digestibility values for raw oat, barley and wheat meals, namely $78 \%, 81-85 \%$ and $48 \%$, respectively, as well as for corn, which had a negative fat digestibility value.

The dogs digested the cereals' crude carbohydrates well, with digestibility values ranging from $81 \%$ for corn to $90 \%$ for rice, which had highest value $(\mathrm{P}<0.001)$. Corn is known to contain starch which is less digestible because of a 
Vol. 13 (2004): 5-17.

strong starch-protein matrix (Hoseney 1986, Murray et al. 1999). The crude carbohydrate digestibility of oat groats was comparable with the values of wheat and better than those of barley $(\mathrm{P}<0.05)$ or corn $(\mathrm{P}<0.01)$. High crude fibre, ADF and TDF content may have reduced the digestibility of crude carbohydrates and protein of barley. The apparent digestibility values of crude carbohydrates are usually lower than those of starch and nitrogen-free extract, which range from $89 \%$ to $99 \%$ in the cooked cereals (Moore et al. 1980, Meyer et al. 1981, Schünemann et al. 1989, Gröner and Pfeffer 1997).

Rice and oat groats were well digested by the dogs, with apparent gross energy digestibilities of $88 \%$ and $86 \%$, respectively. Animals fed rice exhibited better GE digestion than did those fed other cereals $(\mathrm{P}<0.01)$. There was a significant difference between oat groats and the cereals wheat, barley and corn $(\mathrm{P}<0.05)$, with the GE of oat groats being more digestible. For the remaining three cereals, GE digestibility was highest for wheat, intermediate for barley and lowest for corn.

The digestible energy (DE) content ( $\mathrm{MJ} \mathrm{kg}^{-1}$ DM) was highest in oat groats. The DE values for the various cereals were: 17.1 for oat groats, 16.0 for rice, 15.7 for corn, 15.6 for wheat and 15.5 for barley. The differences in DE contents are due to differences in the fat content and total tract nutrient digestibilities between cereals. Digestible energy contents of oat groats, wheat and corn were within the values reported by Gröner and Pfeffer (1997) for extruded cereals. However, the DE contents (MJ kg-1 DM) of dehulled barley (16.4) and rice (17.1) were higher in their study. Kendall and Holme (1982) obtained slightly lower DE values compared to our study for raw oat, barley and wheat meals: 13.7, 14.715.2 and 15.3, respectively. Flaked corn, though, had a higher GE value (16.8 $\left.\mathrm{MJ} \mathrm{kg}^{-1} \mathrm{DM}\right)$ than corn meal in our study.

\section{Effect of the diet on blood glucose and serum insulin responses}

The effect of the diet on blood glucose and serum insulin concentrations is presented in Figure 1. The pre-prandial blood glucose and serum insulin concentrations in the dogs were on

Table 5. Apparent total tract digestibilities (\%) and feed values of cereals calculated by difference; estimated least square means, standard error of mean (SEM) and statistical significance (P).

\begin{tabular}{|c|c|c|c|c|c|c|c|c|}
\hline & Oat groats & Barley & Wheat & Corn & Rice & SEM $_{1}$ & $\mathrm{SEM}_{2}$ & $\mathrm{~F} \mathrm{P} \leq$ \\
\hline Observations & 7 & 7 & 8 & 7 & 7 & & & \\
\hline Organic matter & $85.3^{\mathrm{c}}$ & $82.8^{\mathrm{ab}}$ & $83.5^{\mathrm{a}}$ & $81.4^{\mathrm{b}}$ & $87.8^{\mathrm{d}}$ & 0.61 & 0.57 & 0.001 \\
\hline Crude protein & $80.9^{\mathrm{a}}$ & $77.4^{\mathrm{b}}$ & $77.6^{\mathrm{b}}$ & $74.4^{\mathrm{c}}$ & $79.6^{\mathrm{ab}}$ & 0.89 & 0.83 & 0.001 \\
\hline Acid hydrolysed fat & $93.2^{\mathrm{ab}}$ & $93.0^{\mathrm{abc}}$ & $92.2^{\mathrm{bc}}$ & $92.0^{c}$ & $94.2^{\mathrm{a}}$ & 0.44 & 0.41 & 0.01 \\
\hline Crude carbohydrates & $84.8^{\mathrm{a}}$ & $82.2^{\mathrm{bc}}$ & $83.8^{\mathrm{ab}}$ & $81.2^{\mathrm{c}}$ & $90.8^{d}$ & 0.75 & 0.69 & 0.001 \\
\hline Gross energy & $85.9^{c}$ & $83.6^{\mathrm{ab}}$ & $84.1^{\mathrm{a}}$ & $82.3^{\mathrm{b}}$ & $88.1^{\mathrm{d}}$ & 0.58 & 0.53 & 0.001 \\
\hline \multicolumn{9}{|l|}{ Feed values } \\
\hline Gross energy, $\mathrm{MJ} \mathrm{kg}^{-1} \mathrm{DM}$ & 19.85 & 18.51 & 18.52 & 19.02 & 18.12 & & & \\
\hline Digestible energy, $\mathrm{MJ} \mathrm{kg}^{-1} \mathrm{DM}$ & 17.05 & 15.47 & 15.58 & 15.65 & 15.96 & & & \\
\hline Digestible crude protein, $\mathrm{g} \mathrm{kg}^{-1} \mathrm{DM}$ & 118 & 101 & 107 & 69 & 92 & & & \\
\hline
\end{tabular}

$\mathrm{SEM}_{1}$ is for least square means of oat groats, barley, corn and rice.

$\mathrm{SEM}_{2}$ is for least square mean of wheat.

$\mathrm{a}, \mathrm{b}, \mathrm{c}, \mathrm{d}$ Means with the same row followed by the same letters do not differ significantly $(\mathrm{P} \geq 0.05)$. 
Kempe, R. et al. Composition, digestibility and nutritive value of cereals for dogs

average $5.9 \mathrm{mmol} \mathrm{l}^{-1}$ and $33.1 \mu \mathrm{U} \mathrm{ml}^{-1}$, respectively. At $30 \mathrm{~min}$ the post-prandial glucose curve was significantly lower $(\mathrm{P}<0.05)$ in the $\operatorname{dog} \mathrm{s}$ fed wheat and corn diets in comparison with those fed the barley diet, which had the highest glucose concentration at $30 \mathrm{~min}$. After $30 \mathrm{~min}$, there was no difference in the post-prandial glycaemia curves among the diets, except between the oat groats and basal diets at $90 \min (\mathrm{P}<0.05)$. The maximal post-prandial glucose concentrations were obtained at slightly different time points: at $30 \mathrm{~min}$ in the barley diet, at $60 \mathrm{~min}$ in the rice diet, at $90 \mathrm{~min}$ in the oat groats and wheat diets, and at $120 \mathrm{~min}$ in the corn and basal diets. These results agree with the results of Bednar et al. (2001), where starch of barely, rice and rolled oats where found to be highly and rapidly digestible in the canine small intestine. Differences between the maximal glucose concentrations of the diets were small. However, dogs fed the corn based basal diet had a rather flat post-prandial glucose curve and the maximal glucose concentration was lower $(\mathrm{P}<0.05)$ than in dogs fed the oat groats diet. The greater fat and protein content of basal diet contributed to tendency for a reduction of postprandial increase in serum glucose as shown previously in dogs (Nguyen et al. 1994). After $120 \mathrm{~min}$ there was a trend toward a lower glucose concentration in all the diets.

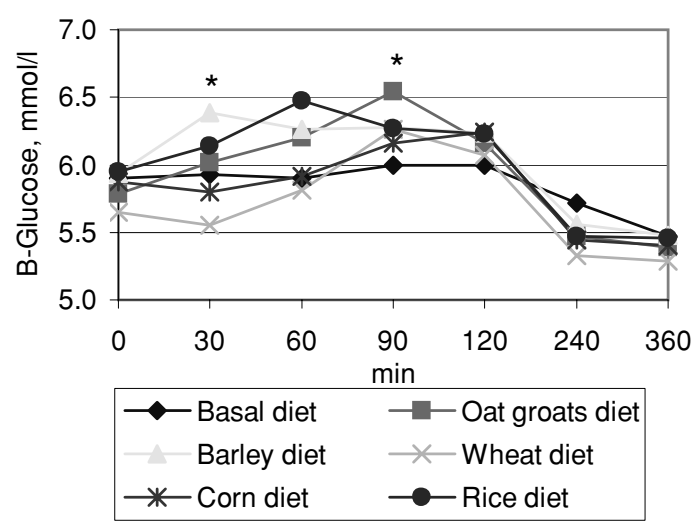

At 30 min the post-prandial insulin curve was significantly lower $(\mathrm{P}<0.01)$ in the wheat and corn diets in comparison with the basal, oat groats, barley and rice diets, which did not differ significantly from each other. At $60 \mathrm{~min}$ the insulin curve in the oat groats diet was still higher $(\mathrm{P}<0.05)$ than in the wheat and corn diets. The maximal post-prandial insulin concentrations were obtained at $90 \mathrm{~min}$ in the rice diet, at 120 min in the oat groats, wheat, corn and barley diets, and at $240 \mathrm{~min}$ in the basal diet. There was no difference in the maximal insulin concentrations between the diets. After 120 min there was a trend toward lower insulin concentrations, except for the basal diet.

\section{Conclusions}

The dogs appeared to digest the cereals with quite a high efficiency. The apparent digestibility coefficients showed that low fibre cereals provide great amount of digestible nutrients and energy to dog diets. Known protein content and energy value of the cereals offer useful information for diet formulation. Any of the cereals tested can be used in dog diets without major negative effects on digestion. The use of rice in the

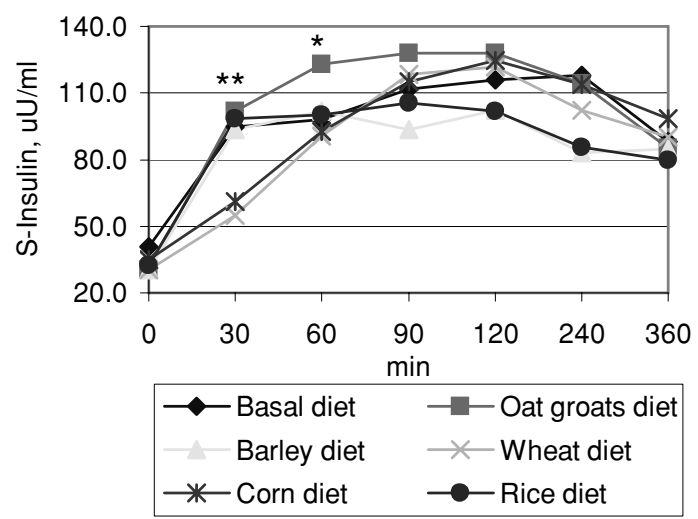

Fig. 1. The effect of diet on blood glucose and serum insulin responses. Statistical significance: $* *(\mathrm{P}<0.01), *(\mathrm{P}<0.05)$. 
basal diet had mainly positive effects on faecal characteristics and nutrient digestibilities, except for crude protein. Oat groats were also found to have mainly positive effects on nutrient digestibilities. Since recent studies in humans have shown that oats are low gluten and suitable for diets of adults with celiac disease, the possibilities of using oats in hypoallergenic diets of gluten-sensitive dogs also need to be studied further.

Consumption of barley and oat groats diets resulted in higher faecal scores, indicating looser stools. This may, in part, be due to the high water-holding capacity of soluble fibres ( $\beta$-glucans) found in oat groats and barley, as well as to the too high proportion of cereals $(50 \%)$ in the diet of sports dogs. Sudden changes to large quantities of newly introduced carbohydrate in the diet may be inadequately digested, until enzyme concentrations increase to meet the changed digestive requirements. According to Lowe and Woodgate (1995) amylase supplements and fibre hydrolysing enzymes used during processing have improved the digestibility and palatability and reduced viscosity of the pet food. As for oats, however, it is also possible to use low $\beta$-glucan varieties of oats (Kolbu, Veli) as well as byproducts of the $\beta$-glucan industry like $\beta$-glucan-free oat feed meal in the nutrition of dogs. Further improvements in digestibility of cereal meals could be overtaken if subjected to optimal heat processing conditions (Moore et al. 1980), although the apparent digestibility of the main organic nutrients were above $74 \%$ in all the cereals in our study.

Proteins as well as carbohydrates in the diet of canine athletes should be highly digestible and quickly utilised by dogs. Feed value, i.e. digestible energy value and digestible crude protein content, were higher in oat groats than in the other cereals in the experiment. Oat groats are a suitable carbohydrate source especially for the nutrition of sports dogs, as it is highly digestible, its feed value is superior to other cereals and it increases the fat and energy contents of premium dog foods if used instead of rice or other cereals. Using dry food where oat groats is the main cereal component, may also promote continual recovery (in addition of post-exercise supplements) of protein and glycogen stores after exercise due to an enhanced glucose and insulin responses of oat groats diet.

Acknowledgements. Authors thank the Ministry of Agriculture and Forestry of Finland and Raisio Feed Ltd (Raisio, Finland) for financing the experiments and Juhani Heikkinen, the owner of the dogs, for his helpful co-operation.

\section{References}

Abrahamsson, M. 1992. Aminosyrasammansättning i svensk havre. Sveriges Lantbruksuniversitet. Uppsala. Fakta-Husdjur nr 2.

AOAC 1990. Official methods of analysis. Association of Official Analytical Chemists Inc., Arlington, VA. $1298 \mathrm{p}$.

Åman, P. \& Fredriksson, H. 2001. Starch and dietary fibre in oat products. In 3rd European Conference on Functional Properties in Oats, Uppsala, Sweden. p. 9-11.

Anderson, J.W., Story, L., Sieling, B., Chen, W.-J.L., Petro, M.S. \& Story, J. 1984. Hypocholesterolemic effects of oat-bran or bean intake for hypercholesterolemic men. American Journal of Clinical Nutrition 40: 1146-1155.

Batt, R.M., Carter, M.W. \& McLean, L. 1984. Morphological and biochemical studies of a naturally occurring enteropathy in the Irish setter dog: a comparison with celiac disease in man. Research in Veterinary Science 37: 339-346.

Batt, R.M., McLean, L. \& Carter, M.W. 1987. Sequential morphologic and biochemical studies of naturallyoccurring wheat-sensitive enteropathy in Irish setter dogs. Digestive Disease and Science 32: 184-194.

Bednar, G.E., Patil, A.R., Murray, S.M., Grieshop, D.M., Merchen, N.R. \& Fahey, G.C., Jr. 2001. Starch and fiber fractions in selected food and feed ingredients affect their small intestinal digestibility and fermentability and their large bowel fermentability in vitro in a canine model. Journal of Nutrition 131: 276-286.

Blaxter, A.C., Cripps, P.J. \& Gruffydd-Jones, T.J. 1990. Dietary fibre and post prandial hyperglycaemia in normal and diabetic dogs. Journal of Small Animal Practice 31: 229-233.

Davidson, M.H., Dugan, L.D., Burns, J.H., Bova, J., Story, K. \& Drennan, K.B. 1991. The hypocholesterolemic effects of $\beta$-glucan in oatmeal and oat bran. The Journal of the American Medical Association 265: 18331839.

Davis, A. \& Hall, W.B. 1969. Cyclic change-over designs. Biometrika 56: 283-293.

Fahey, G.C., Jr., Merchen, N.R., Corbin, J.E., Hamilton, 
Kempe, R. et al. Composition, digestibility and nutritive value of cereals for dogs

A.K., Bauer, L.L., Titgemeyer, E.C. \& Hirakawa, D.A. 1992. Dietary fiber for dogs: III. Effects of beet pulp and oat fiber additions to dog diets on nutrient intake, digestibility, metabolizable energy, and digesta mean retention time. Journal of Animal Science 70: 1169-1174.

Gröner, T. \& Pfeffer, E. 1997. Digestibility of organic matter and digestible energy in single ingredients of extruded dog feeds and their effects on faecal dry matter concentration and consistency. Journal of Animal Physiology and Animal Nutrition 77: 214-220.

Hoseney, R.C. 1986. Principles of cereal science and technology. American Association of Cereal Chemists, Inc. St. Paul, Minnesota, USA. 327 p.

Janatuinen, E., Kemppainen, T., Kosma, V.-M., Heikkinen, M., Julkunen, R. \& Uusitupa, M. 1996. Oats in coeliac diet; a 5-year follow-up study. Seventh International Symposium on Coeliac Disease, Tampere, Finland. Free paper abstracts A128.

Janatuinen, E.K., Pikkarainen, P.H., Kemppainen, T.A., Kosma, V.-M., Järvinen, R.M.K., Uusitupa, M.I.J. \& Julkunen, R.J.K. 1995. Comparison of diets with and without oats in adults with celiac disease. The New England Journal of Medicine 333: 1033-1038.

Kempe, R., Särkijärvi, S., Saastamoinen, M. \& Kommeri, U. 2001. Kaura hevosten ja koirien ruokinnassa ja rehujen raaka-aineena. In: Salovaara, H. \& SontagStrohm, T. (eds.). Kaurasta elinvoimaa. Maa- ja metsätalousministeriön kansallisen kauraohjelman tutkimushankkeet 1998-2000. Helsinki, Yliopistopaino. p. $109-126$.

Kendall, P.T. \& Holme, D.W. 1982. Studies on the digestibility of soya bean products, cereals, cereal and plant by-products in diets of dogs. Journal of the Science of Food and Agriculture 33: 813-822.

Kienzle, E., Dobenecker, B. \& Eber, S. 2001. Effect of cellulose on the digestibility of high starch versus high fat diets in dogs. Journal of Animal Physiology and Animal Nutrition 85: 174-185.

Klopfenstein, C.F. 1988. The role of cereal $\beta$-glucans in nutrition and health. Cereal Foods World 33: 865869.

Lee, S.C., Prosky L. \& De Vries, J.W. 1992. Determination of total, soluble and insoluble dietary fiber in foods: enzymatic-gravimetric method, MES-TRIS buffer: collaborative study. Journal of AOAC International 75: 395-416.

Lewis, L.D., Magerkurth, J.H., Roudebush, P., Morris, M.L., Mitchell, E.E. \& Teeter, S.M. 1994. Stool characteristics, gastrointestinal transit time and nutrient digestibility in dogs fed different fiber sources. Journal of Nutrition 124: 2716S-2718S.

Lowe, J.A. \& Woodgate, S. 1995. The production of, and rationale for, digests in pet food design. In: Biotechnology in the feed industry. 11th Annual Symposium. Alltech Technical Publications. $337 \mathrm{p}$.

McCleary, B.V. \& Codd, R. 1991. Measurement of (1-3)(1$4)-\beta$ - $D$-glucan in barley and oats: a streamlined enzymatic procedure. Journal of Science of Food and Agriculture 55: 303-312.

McCleary, B.V., Solah, V. \& Gibson, T.S. 1994. Quantitative measurement of total starch in cereal flours and products. Journal of Cereal Science 20: 51-58.

McMullen, M.S. 1991. Oats. In: Kulp, K. \& Lorenz, K.J. (eds.). Handbook of cereal science and technology. New York, Marcel Dekker, Inc. p. 199-232.

Meyer, H. von, Schmitt, P.-J. \& Heckötter, E. 1981. Nährstoffgehalt und verdaulichkeit von Futtermitteln für Hunde. Übers. Tierernährung 9: 71-104.

Meyer, H. \& Zentek, J. 1998. Ernährung des Hundes: Grundlagen, Fütterung, Diätetik. 3rd ed. Berlin/Wien, Blackwell Wissenschafts-Verlag. 314 p.

Moore, M.L., Fottler, H.J., Fahey, G.C., Jr. \& Corbin, J.E. 1980. Utilization of corn-soybean meal-substituted diets by dogs. Journal of Animal Science 50: 892896.

Murray, S.M., Fahey, G.C., Jr., Merchen, N.R., Sunvold, G.D. \& Reinhart, G.A. 1999. Evaluation of selected high-starch flours as ingredients in canine diets. Journal of Animal Science 77: 2180-2186.

Nelson, R.W. 1992. Dietary management of diabetes mellitus. Journal of Small Animal Practice 33: 213217.

Nguyen, P., Dumon, H., Buttin, P. Martin, L. \& Gouro, A.S. 1994. Composition of meal influences changes in postprandial incremental glucose and insulin in healthy dogs. Journal of Nutrition 124:2707S-2711S.

Oksman-Caldentay, K.-M., Laitila, A., Wilhelmson, A., Heiniö, R.-L., Outinen, M., Kaukovirta-Norja, A., Lehtinen, P., Plaami, S., Sontag-Strohm, T., Mikola, M. \& Poutanen, K. 1999. Kaura elintarvikeraaka-aineena. VTT tiedotteita. p. 120.

Robertson, J.B. \& Van Soest, P.J. 1981. The detergent system of analysis and its application to human foods. In: James, W.D.T. \& Theander, O. (eds.). The analyses of dietary fibre in foods. New York, NY, Marcell Dekker. p. 123-158.

SAS 1998. SAS/STAT User's Guide (Release 6.03). SAS Institute, Inc., Cary, NC. 1686 p.

Schneider, B.H. \& Flatt, W.P. 1975. The evaluation of feeds through digestibility experiments. The University of Georgia Press, USA. p. 423.

Schünemann, C. von, Mühlum, A., Junker, S., Wilfarth, H. \& Meyer, H. 1989. Praecaecale und postileale Verdaulichkeit verschiedener Stärken sowie $\mathrm{pH}$-Werte und Gehalte an organischen Säuren in Darmchymus und Faeces. Advances in Animal Nutrition and Animal Physiology 19: 44-48.

Sontag-Strohm, T., Salovaara, H. \& Brinck, O. 2001. Kauratuotteiden puhtauden varmistaminen ja prolamiinien tila. In: Salovaara, H. \& Sontag-Strohm, T. (eds.). Kaurasta elinvoimaa. Helsingin Yliopisto, Elintarviketeknologian laitos. EKT-sarja 1221. Helsinki, Yliopistopaino. p. 141-147.

Sunvold, G.D., Fahey, G.C., Jr., Merchen, N.R., Titgemeyer, E.C., Bourquin, L.D., Bauer, L.L. \& Reinhart, G.A. 1995. Dietary fiber for dogs IV: In vitro fermentation of selected fiber sources by dog fecal inoculum and in vivo digestion and metabolism of fiber-supplemented diets. Journal of Animal Science 73: 1099-1109.

Walker, J.A., Harmon, D.L., Gross, K.L. \& Collings, G.F. 1994. Evaluation of nutrient utilization in the canine using the ileal cannulation technique. Journal of $\mathrm{Nu}$ trition 124: 2672S-2676S. 
Vol. 13 (2004): 5-17.

\title{
SELOSTUS
}

\section{Kypsennettyjen viljojen sulavuus ja ravitsemuksellinen arvo koirien ruokinnassa}

\author{
Riitta Kempe, Markku Saastamoinen, Seppo Hyyppä ja Kurt Smeds \\ MTT (Maa- ja elintarviketalouden tutkimuskeskus) ja Rehuraisio
}

Kaikki koirien kuivaruuat ovat pääosin viljapohjaisia ja viljojen osuus niissä on tyypillisesti 30-60\%. Viljat ovat hyvä ja halpa energian ja hiilihydraattien lähde koirien ruokinnassa, mutta viljoista on suhteellisen vähän tutkittua tietoa. Koiran kyvystä hyödyntää viljojen ravintoaineita täytyy saada lisää tietoa kaupallisten ruokien kysynnän kasvaessa. Teollisten ruokien suunnitteluun tarvitaan täsmällistä tietoa viljojen ravintoainekoostumuksesta, sulavuudesta ja rehuarvoista koiralla. Niinpä tässä tutkimuksessa määritettiin kuoritun kauran ravintoaineiden sulavuus ja energia-arvo koiralla verrattuna muihin yleisesti koiran ruokinnassa käytettyihin viljoihin. Tutkimus oli Maa- ja metsätalousministeriön rahoittaman kansallisen kauraohjelman Kaura yksimahaisten eläinten rehuna ja rehun raaka-aineena -hankkeen ensimmäinen osa ja sen tuloksia käytettiin kuivaruuan tuotekehitykseen.

Sulavuuskoe tehtiin 12 rekikoiralla, ja jokainen koira sai ruuaksi neljää eri viljadieettiä. Tutkittavat viljat (kuorittu kaura, ohra, vehnä, maissi ja riisi) kypsennettiin Rehuraision autoklaavissa ja jauhettiin sen jälkeen. Kokeen perusrehuna oli kuivaruoka (Baron ${ }^{\circledR}$ Exel, Rehuraisio Oy) ja tutkittavaa viljaa lisättiin perusrehuun $30 \%$.

Koirat pystyivät käyttämään hyväkseen kypsennettyjä viljoja hyvin. Kuoritun kauran sulavan ener- gian ja valkuaisen määrät olivat korkeammat kuin muilla viljoilla. Kuorittu kaura sopii hyvin erityisesti urheilevien koirien ruokintaan, koska se on erittäin hyvin sulavaa, sen rehuarvo on korkeampi kuin muiden viljojen ja se lisää kuivaruuan rasva- ja energiapitoisuutta. Riisi vaikutti edullisesti dieetin ravintoaineiden sulavuuteen ja kiinteytti ulostetta. Ohran suuri kuitupitoisuus heikensi jonkin verran ohran ravintoaineiden sulavuutta ja lisäsi ulosteen määrää. Kaurassa ja ohrassa on paljon liukoista kuitua, $\beta$-glukaania, joka pystyy sitomaan paljon vettä ulosteeseen ja näin ollen löystyttää hieman ulostetta. Vehnä oli lähes kauran veroinen raaka-aine koirien ruokinnassa, vaikka sen ravintoaineiden sulavuudet ja rehuarvo olivat heikompia kuin kuoritun kauran. Maissi sen sijaan osoittautui tässä tutkimuksessa olevan huonoiten koiran hyväksikäytettävissä, vaikka sen rasvapitoisuus on suuri ja sitä käytetään yleisesti koirien kuivaruuissa. Tutkituista viljoista kaura, riisi ja maissi ovat gluteiinittomia vaihtoehtoja koiran ruokintaan. Kaura on Suomessa vapautettu mm. keliakiaa sairastavien ruokavalioon. Koirien gluteiinienteropatia on ihmisten keliakia-sairauden kaltainen, joten kaura todennäköisesti soveltuu hyvin myös allergisten koirien ruuan raaka-aineeksi. 